\title{
Original Research \\ THE IMPLICATION OF MASTECTOMY FLAP FIXATION IN DECREASING THE INCIDENCE OF SEROMA ON BREAST CANCER PATIENT
}

\author{
Patric Christ Ardhika Kustono ${ }^{1}$, Heru Purwanto ${ }^{2,3}$ \\ ${ }^{1}$ Resident of General Surgery, Faculty of Medicine, Universitas Airlangga, Surabaya, Indonesia \\ ${ }^{2}$ Division of Oncologic Surgery, Department of Surgery, Faculty of Medicine, Universitas Airlangga, Surabaya, \\ Indonesia \\ ${ }^{3}$ Siloam Hospital Surabaya, Surabaya, Indonesoa
}

\begin{abstract}
Seroma is the most common complication after mastectomy procedure. This study was conducted to analyse the treatment of flap fixation in seroma production after modified radical mastectomy in breast cancer patients. An interventional prospective clinical study in 35 female patients with breast cancer who underwent modified radical mastectomy with flap fixation in the period August-December 2018 and 35 patients without flap fixation through historical data of patient who underwent modified radical mastectomy in the period 2016-2017 at RSUD Dr. Soetomo Surabaya. Data of characteristic patients will be presented descriptively and analyzed statistically using the appropriate test. The result of the statistical test using Chi Square with a 95\% significance level obtained a value of $p=0.000$ ( $p<0.05)$, it was said statistically that there was a significant relationship between the treatment of flap fixation and the time of releasing drain in this study. The treatment of flap fixation will reduce drainage time by <10 days. The results of the odds ratio (OR) obtained OR = 16 and CI: 95\% (4.094 - 62.528) which means that the treatment of flap fixation will reduce the releasing time of the drain 16 times more effectively than not performing flap fixation. Correlation between the treatment of flap fixation and the time of releasing drain was considered to be moderately positive (Contingency Coefficient Chi Square = 0.476). There was a significant reduction in the number of seroma assessed from the time of releasing drain faster in patients who underwent modified radical mastectomy with flap fixation.
\end{abstract}

Keywords: Seroma; flap fixation; modified radical mastectomy; health risk

Correspondence: Patric Christ Ardhika Kustono, Residence of General Surgery, Medical Faculty of Airlangga University Surabaya, Indonesia. Email: patricardhika8@gmail.com

How to cite Kustono, P. C. A., \& Purwanto, H. (2021). The Implication of Mastectomy Flap Fixation in Decreasing the Incidence of Seroma on Breast Cancer Patient. Folia Medica Indonesiana, 57(4), 277-282.

https://doi.org/10.20473/fmi.v57i4.12009

pISSN:2355-8393 • eISSN: 2599-056x • doi: 10.20473/fmi.v57i4.12009 OFol Med Indones. 2021;57:277-282

- Submitted 23 Feb $2021 \bullet$ Revised 21 Oct $2021 \bullet$ Accepted 17 Nov 2021 OPublished 7 Dec 2021

- Open access under CC-BY-NC-SA license • Available at https://e-journal.unair.ac.id/FMI/

Hi口[ए]

1. Modification of radical mastectomy with flap fixation treatment in seroma production in breast cancer patients was anal yzed.

2. The number of seromas from the drain removal time in patients undergoing modified radical mastectomy with flap fixation was reduced.

\section{INTRODUCTION}

Breast cancer in Indonesia is a cancer with the highest percentage of new cases currently, at $30.5 \%$ of all types of cancer in Indonesian women (GLOBOCAN). Modified radical mastectomy is still one of the main therapies used to treat breast cancer in Indonesia (Purwanto et al. 2015, van Bastelaar et al. 2016, Sobri et al. 2017). Seroma is the most common complication after mastectomy. Seroma in patients after mastectomy will inhibit wound healing through infection (10\%), wound dehiscence $(1.3 \%)$, flap necrosis $(2.6 \%)$, and the incidence of flap necrosis is as high as $17.8 \%$ (Bland 2011, Yildiz \& Sulu 2013).
In the end, these complications cause discomfort to the patient and delays the administration of adjuvant therapy. Seroma formation is predicted when we minimize production by mechanical closure to reduce dead space by sewing flap mastectomy on the base (Bland 2011, Sakkary 2012, Brunicardi 2014). As a result of minimal seroma formation, it is expected that post mastectomy complications should also be significantly reduced. The purpose of this study was to analyze the relationship of flap fixation techniques in reducing seroma production after modified radical mastectomy in breast cancer patients and analyzed other factors associated with seroma formation after mastectomy. 


\section{MATERIALS AND METHODS}

This study was an interventional prospective clinical study conducted at Dr. Soetomo General Academic Hospital, Surabaya, by involving women with breast cancer undergoing modified radical mastectomy with primary closure on the period between AugustDecember 2018 taken from random sampling. Subcutaneous flap mastectomy suturing technique in the pectoralis major muscle and serratus anterior. Suturing is made between the subcutis part of the flap with the pectoralis muscle and serratus anterior muscle with an inside simple interrupted technique.

The material used in this study was 3.0 absorbable monofilament suture using 3 knots. The control group used medical record data taken from medical record data of women with breast cancer who underwent modified radical mastectomy with primary closure for 2017-2018 period. The drain was removed after the drain fluid production was $\leq 30 \mathrm{cc} / 24$ hours. Patient data included age, BMI, tumor size, anatomical pathologic grading, staging, tumor location, chemotherapy cycle, length of operation, and drainage time were tabulated and analyzed using statistical tests.

\section{RESULTS}

This study involves 70 patients with modified radical mastectomy. Using 35 patients as a sample size in each group. It was found that the mean age of the subjects undergoing modified radical mastectomy with flap fixation was $50.74 \pm 9.36$ and patients undergoing modified radical mastectomy without flap fixation were $48.57 \pm 8.78$. The characteristics of the study subjects were based on Body Mass Index in patients with flap fixation $25.25 \pm 3.48 \mathrm{~kg} / \mathrm{m} 2$ and those without flap fixation $25.98 \pm 4.90 \mathrm{~kg} / \mathrm{m} 2$ (Table 1).

From tumor size, the tumor volume of patients undergoing modified radical mastectomy with flap fixation was $37.75 \pm 26.85 \mathrm{~cm}^{3}$, while the tumor volume of patients undergoing modified radical mastectomy without flap fixation was $26.55 \pm 22.21 \mathrm{~cm}^{3}$. Based on histopathological grading in the flap fixation group, grade III consisted of 25 patients (71.4\%), while in the group without flap fixation with grade III was 22 patients $(62.9 \%)$. Based on staging, the most flap and non-fixation fixation groups, 29 patients were in advanced stage $(82.9 \%)$ with flap fixation and 23 $(65.7 \%)$ without flap fixation. Most of tumor locations

Table 1. Subject's characteristics

\begin{tabular}{|c|c|c|c|}
\hline \multirow{2}{*}{ Characteristics } & \multicolumn{2}{|c|}{ Total Sample } & \multirow{2}{*}{$\mathrm{p}(<0,05)$} \\
\hline & Flap Fixation $(n=35)$ & Without Flap Fixation $(\mathrm{n}=35)$ & \\
\hline \multirow{2}{*}{ Age (years) } & 50.74 & 48.57 & 0.320 \\
\hline & SD: 9.36 & SD: 8,78 & \\
\hline \multirow[t]{2}{*}{ Body Weight (kg) } & 58.49 & 58.91 & 0.634 \\
\hline & SD: 8.79 & SD: 11,82 & \\
\hline \multirow[t]{2}{*}{ Body Height $(\mathrm{cm})$} & 152.51 & 150.46 & 0.072 \\
\hline & SD: 3.58 & SD: 5.61 & \\
\hline \multirow[t]{2}{*}{ BMI (kg/m2) } & 25.25 & 25.98 & 0.618 \\
\hline & SD: 3.48 & SD: 4.90 & \\
\hline \multirow{2}{*}{ Tumor Size (Volume: $\mathrm{cm}^{3}$ ) } & 37.75 & 26.55 & 0.049 \\
\hline & SD: 26.85 & SD: 22.21 & \\
\hline \multirow[t]{4}{*}{ PA Grading PA } & No Data: $1(2.9 \%)$ & No Data: $3(8,6 \%)$ & \\
\hline & I: $3(8.6 \%)$ & I: $5(14.3 \%)$ & 0.333 \\
\hline & II: $6(17.1 \%)$ & II: 5 (14.3\%) & \\
\hline & III: 25 (7.4\%) & III: $22(62.9 \%)$ & \\
\hline \multirow[t]{2}{*}{ Staging } & Early Stage: $6(17.1 \%)$ & Early Stage: 12 (34.3\%) & 0.103 \\
\hline & Advance Stage: $29(82.9 \%)$ & Advance Stage: 23 (65.7\%) & \\
\hline Tumor Location: & No Data: $0(0 \%)$ & No Data: 4 (11.4\%) & \\
\hline 1: Medial Superior Quadrant & $1: 4(11.4 \%)$ & $1: 4(11.4 \%)$ & \\
\hline 2: Lateral Superior Quadrant & 2: $6(17.1 \%)$ & 2: $5(14.3 \%)$ & 0.310 \\
\hline 3: Lateral Inferior Quadrant & 3: $5(14.3 \%)$ & 3: $4(11.4 \%)$ & \\
\hline 4: Medial Inferior Quadrant & $4: 2(5.7 \%)$ & $4: 3(8.6 \%)$ & \\
\hline 5: Central & 5: $18(51.4 \%)$ & 5: $15(42.9 \%)$ & \\
\hline \multirow{2}{*}{ Chemotherapy Cycle (times) } & 3.00 & 3.23 & 0.891 \\
\hline & SD:2.95 & SD: 3.1 & \\
\hline \multirow[t]{2}{*}{ Operation Time (hours) } & 2.57 & 2.66 & 0.668 \\
\hline & SD: 0.66 & SD: 0.73 & \\
\hline
\end{tabular}


in the central quadrant in each group were $18(51.4 \%)$ in the flap fixation group, and $15(42.9 \%)$ in the without flap fixation group.

Based on the history of neoadjuvant chemotherapy administration, the flap fixation group neoadjuvant chemotherapy administration was $3 \pm 2.95$ cycles and $3.23 \pm 3.1$ cycles in group without flap fixation. The mean length of surgery in the flap fixation group was $2.57 \pm 0.66$ hours and $2.66 \pm 0.73$ in group without fixation.

In Table 1, $\mathrm{p}$ values have been found using Chi Square analysis to show the relationship between risk factors and flap fixation in patients undergoing modified radical mastectomy. It appeared that only the size of the tumor volume had a significant difference between the flap fixation group with without flap fixation group with $\mathrm{p}$ value $=0.049(\mathrm{p}<0.05)$.

Furthermore, the overall drainage time in patients undergoing modified radical mastectomy performed ith flap fi ation and ithoutflap fi ation group had resulted that the statistical test using hi uare ith a significance leve o tained p[value of . $p$, so that there as a statistically significant relationship et een the treatment of flap fi ation and drainage release time in this study he treatment of flap fi ation ill reduce drainage time y days

Table 2. Relationship between flap fixation intervention and drain removal time

\begin{tabular}{|c|c|c|c|c|c|c|}
\hline \multirow{3}{*}{$\begin{array}{l}\text { Flap } \\
\text { Fixation }\end{array}$} & \multicolumn{4}{|c|}{$\begin{array}{l}\text { Drain Removal Time } \\
\text { (Day) }\end{array}$} & \multirow{3}{*}{$\begin{array}{c}P \\
(p<0,0 \\
5)\end{array}$} & \multirow{3}{*}{ OR } \\
\hline & \multicolumn{2}{|c|}{$\leq 10$} & \multicolumn{2}{|c|}{$>10$} & & \\
\hline & $\mathrm{f}$ & $\%$ & $\mathrm{~F}$ & $\%$ & & \\
\hline Yes & 32 & 69.6 & 3 & 12.5 & & \\
\hline No & 14 & 30.4 & 21 & 87.5 & 0.000 & 16 \\
\hline Total & 46 & 100 & 24 & 100 & & \\
\hline
\end{tabular}

The odds ratio results were $\mathrm{OR}=16$ and CI: $95 \%$ (4,094-62.528), and showed that the action of flap fixation could reduce the drain removal time 16 times more effectively than without flap fixation. Relationship strength (correlation) between the treatment of flap fixation and the discharge time was considered to be moderately positive (Contingency Coefficient Chi Square $=0.476$ ).

Table 3 shows variables with significant correlation $(\mathrm{p}<0.05)$ : BMI $(\mathrm{p}=0.019)$, tumor size $(\mathrm{p}=0.017)$ with the drain removal time apart from the flap fixation intervention $(\mathrm{p}=0.000)$. However, there was a strong correlation (correlation coefficient $>0.5$ ) between flap fixation intervention and drain removal time (Correlation Coefficient 0.665). BMI had a weak correlation (Correlation Coefficient 0.10.3) with drain removal time (Correlation Coefficient $=0.280$ ), and Tumor Size had a weak correlation with drain removal time (Correlation Coefficient $=0.285$ ).

Table 3. Multivariate correlation analysis: Spearman's rho test

\begin{tabular}{lcc}
\hline Variable & $\begin{array}{c}\text { Drain } \\
\text { Removal Time } \\
(\mathrm{p}<0,05)\end{array}$ & $\begin{array}{c}\text { Correlation } \\
\text { Coefficient }\end{array}$ \\
\hline Age & 0.486 & 0.085 \\
BMI $(\mathrm{kg} / \mathrm{m} 2)$ & 0.019 & 0.280 \\
Tumor Size $(\mathrm{cm} 2)$ & 0.017 & 0.285 \\
Hemotherapy Cycle & 0.639 & 0.057 \\
Grading & 0.050 & 0.236 \\
Staging & 0.289 & 0.129 \\
Tumor Location & 0.205 & 0.153 \\
Operation Time & 0.803 & 0.030 \\
Flap Fixation & 0.000 & 0.665 \\
\hline
\end{tabular}

\section{DISCUSSION}

There are several factors that can influence the formation of post-mastectomy seroma including age, breast volume, tumor size, positive lymph node counts, intraoperative cautery, tissue damage, axillary dissection extension, tumor histopathology, length of operation, obesity, and hypertension history (Dahri et al. 2011, Zielinski et al. 2013, Faisal et al. 2016). In this study, several of these factors might influence seroma production (DeVita et al. 2014). However, some parameters in this study had no significant differences between without flap fixation group and the flap fixation group, except for tumor volume. In accordance with Table 1 , only the size of tumor volume had a significant difference between the flap fixation group with without flap fixation group with $\mathrm{p}=0.049(\mathrm{p}<0.05)$.

The formation of seroma as a complication of a mastectomy surgery can cause some problems in patients. These include sensations of discomfort, wound healing delay, flap necrosis, wound dehiscence, extended length of hospital stay, increased risk of infection, more frequent visits to clinics, increased rates of surgical intervention, poor cosmetics, higher overall costs, and delay in adjuvant therapy administration (Dahri et al. 2011, Sakkary 2012).

Various efforts were made to reduce seroma production to minimize complications due to excessive seroma formation. Obliteration of dead space through fixation of skin flaps on the structure of the chest wall is an attempt to reduce seroma formation (Zielinski et al. 2013, DeVita et al. 2014, Faisal et al. 2016). Variety of flap fixation 
techniques were developed and researched as an alternative method that can be supplemented postsurgical procedures that might leave extensive defects, such as post mastectomy. In this study, the reduction in seroma production was measured by calculating the drain removal time when seroma production was <30 cc seroma/day. Using faster drain removal, a smaller number of seroma production is expected (Yilmaz et al. 2011, Kurnia et al. 2016).

Dead space post modification of radical mastectomy has the potential to cause a build-up of serous fluid that occupies the cavity. This is the most common complication and occurs immediately after mastectomy. Although not lifethreatening, this can cause morbidity in patients after mastectomy. Usually, seroma will be absorbed in a few weeks. If the seroma fluid is formed excessively, the skin will stretch that can cause discomfort on patients. In some patients, this buildup of fluid will present several problems, such as prolonging the treatment period, and it will increase the cost of treatment. In addition, it will also be aspirated repeatedly, so that the patient will feel uncomfortable (Mackay-Wiggan 2016, Ouldamer et al. 2016, Ridha 2017).

In seroma fluid analysis, several inflammatory mediators, such as TNFa and IL6 activate monocytes and macrophages. This shows that seroma formation results from an acute reaction to the inflammatory process during the first phase of the wound healing process. With the basis of the inflammatory process, the conditions that can inhibit or reduce the severity of the inflammatory process will be able to reduce the occurrence of seroma (Sampathraju \& Rodrigues 2010, Yilmaz et al. 2011, Suyatno \& Pasaribu 2014, MackayWiggan 2016).

In this study, flap fixation intervention in patients after modified radical mastectomy was proven to have reduced seroma assessed from faster drain removal than the without flap fixation intervention group $(\mathrm{p}=0,000)$ (Table 2). Flap fixing will reduce the drain removal time sixteen times more effectively than without flap fixation. Reduction of dead space due to flaps suturing on the muscle base has been effective in reducing seroma production.

In the reduction of seroma production through flap suturing, a study also found that a reduction in the amount of drained fluid in patients with flap fixation in the chest wall muscle compared to conventional flap closure (Cong et al. 2020). A decrease in the incidence of seroma production, reduction in drain removal time and the amount of drainage production were achieved by fixing skin flaps in the chest wall muscles to obliterate dead space (Sakkary 2012). It was also found that there was a difference between seroma formation in mastectomy patients and skin flap fixation (van Bastelaar et al. 2016, Ridha et al. 2017). In addition, there was a difference between seroma formation in mastectomy patients and skin flap fixation with $\mathrm{p}=0.002(\mathrm{p}<0.05)$ (Sakkary 2012, van Bastelaar et al. 2016).

Another study also found fewer seroma in patients who had modified radical mastectomy with flap fixation compared with patients without flap fixation with $\mathrm{p}=0.003 \quad(\mathrm{p}<0.05)$ (Skandalakis \& Skandalakis 2014, Ridha 2017). However, they used different technique made by interrupted suture flap fixation to the wound base using 3.0 unabsorbable polyfilament suture with vertical mattress technique, i.e., the needle was passed from curtis to the subcutaneous and took the muscle underneath. Then, the needle was returned from subcutis to the cutis and tied the knot from outside, so that the skin flap was fixed with the chest wall (Zollinger \& Ellison 2011, Zielinski et al. 2013, Audrina 2014).

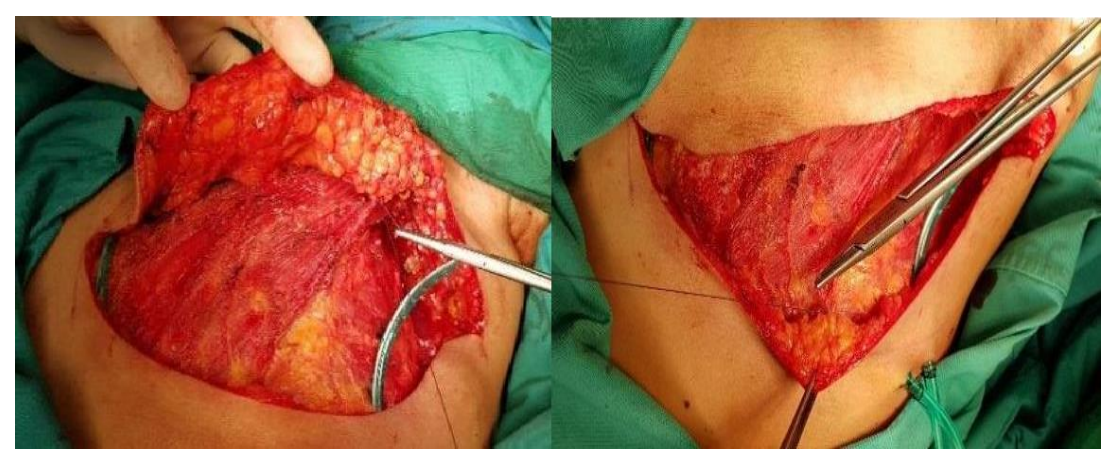

(a) (b)

Figure 1. (a) Subcuticular suturing of superior flap on the pectoralis major muscle, (b) Subcuticular suturing of inferior flap on the pectoralis major muscle 
The suturing technique used in this study was the subcutis flap mastectomy in the pectoralis major muscle and the serratus anterior muscle (Figure 1). Suturing is carried out between the subcutis flap and the pectoralis muscle, and the serratus anterior muscle with an inside simple interrupted knot technique. The suture material used was 3.0 absorbable monofilament using 3 knots. This suturing technique was chosen, because it had good cosmetics and did not need to be removed later after intervention. Subcuticular sutures did not damage the flap and were cosmetically good and relatively safe. Complications due to flap suturing in the chest muscles, such as bleeding and pain were not found in patients who underwent flap suturing after modified radical mastectomy.

Analysis on other factors in Table 3 which also influenced seroma production after modification of radical mastectomy were age, BMI, tumor size, history of neoadjuvant chemotherapy, histopathological grade, histopathology type, staging, tumor location, and duration of operation. It was found that there was an influence of BMI $(\mathrm{p}=0.019)$ and tumor size $(\mathrm{p}=0.017)$ on the number of postoperative modified radical mastectomy seroma production apart from the flap fixation suture factor. However, the correlation of BMI and tumor size to the reduction in seroma was not as strong as the correlation between the intervention of flap fixation on the reduction of seroma production (Correlation Coefficient 0.665).

\section{Strength and limitation}

The study is conducted at a single center, $\square$ hich may limit the generali $\square$ a $\square$ ility of the results to other populations or institutions $\square$ [his study only evaluates the effect of flap fi $\square$ ation on seroma production and does not assess other complications or outcomes] he study provides clinically relevant information on reducing the time of releasing the drain and reducing the num $\square$ er of seromas $\square$ ut, does not the severity or volume of seromas or the clinical significance of reducing the time of releasing chute $\square$

This study was non-homogeneous data between fixation groups and without fixation groups in terms of tumor size and BMI. In the flap fixation group, the tumor size was greater than group without flap fixation, whereas BMI was influenced by the height of the patient, and the flap fixation group had a greater average BMI than group without flap fixation. The use of medical record data in the control group might also have influenced the result of this study.

\section{CONCLUSION}

Seroma is a build-up of serous fluid in a postoperative cavity clinically proven due to dead space formation under the skin flap and in axilla in post mastectomy patients. The formation of seroma as a complication of a mastectomy surgery can cause problems in patients. Various efforts were made to reduce seroma production in the hope of minimizing complications due to excessive seroma formation. Obliteration of dead space through fixation of skin flaps on the structure of the chest wall is one of the attempts to reduce seroma formation.

Flap fixation has been shown to reduce seroma formation seen from faster time of drain removal than without flap fixation. There was a significant reduction in the number of seromas assessed from the time of drain removal in patients undergoing modified radical mastectomy with flap fixation. The recommended flap fixation is subcuticular sutures because it has better cosmetics. However, further research is needed to gather data with fixation groups and control other risk factors that have the potential to influence the amount of seroma production.

\section{Acknowledgment}

पhe author than $\square$ s to $\square$ ivision of $\square$ ncologic Durgery, Department of Durgery, Faculty of $\square$ edicine, $\square$ niversitas $\square$ irlangga and $\square \mathrm{r} \square \square$ oetomo

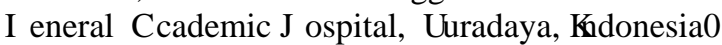

\section{Conflict of interest}

None.

\section{Funding disclosure}

None.

\section{Author contribution}

$\square$ contri $\square$ uted in design of the research, data analysis, and collected datam $\square \square$ rote the manuscript and final revision $\square$

\section{REFERENCES}

Audrina, GW (2014). Faktor-faktor yang mempengaruhi tingkat keberhasilan pemberian kemoterapi pada pasien penderita kanker 
payudara di RSUD Dr. Soetomo dengan menggunakan regresi logistik ordinal. Jurnal Sains dan Seni 3, 2337-3520.

Bland KI (2011). Master techniques in general surgery: Breast surgery. Lippincott Williams \& Wilkins, Philadelphia.

Brunicardi FC (2014). Schwartz's principles of surgery: 10th ed. Mc GrawHill, Philadephia.

Cong Y, Cao J, Qiao G, et al (2020). Fascia suture technique is a simple approach to reduce postmastectomy seroma formation. Journal of Breast Cancer 23, 533-541.

Dahri FJ, Awan MS, Qazi AR, et al (2011). Early wound complications following modifeid radical mastectomy with axillary clearance. Journal of surgery Pakistan 16, 165-169.

DeVita V, Lawrence TS, Rosenberg SA (eds) (2014). Cancer: Principles and practice of oncology: $10^{\text {th }}$ ed. Wolters Kluwer Health Adis (ESP), United States.

Edge SB (2010). Breast. In: AJCC cancer staging manual. Springer, New York.

Faisal M, Abu-Elela ST, Mostafa W, et al (2016). Efficacy of axillary exclusion on seroma formation after modified radical mastectomy. World Journal of Surgical Oncology 14, 1-5.

Kurnia A, Suhandi A, Budiningsih S (2016). Correlation between obesity and seroma following modified radical mastectomy. New Ropanasuri J Surg 5, 3-6.

Mackay-Wiggan J (2016). Suturing techniques: Background, indications, technical consideration. Available from https://emedicine.medscape.com. Accessed January 11, 2020.

Ouldamer L, Bonastre J, Brunet-Houdard S, et al (2016). Dead space closure with quilting suture versus conventional closure with drainage for thr prevention of seroma after mastectomy for breast cancer (QUISERMAS): Protocol for a multicentre randomised controlled trial. BMJ Open 6, 1-8.

Purwanto H, Handojo J, Haryono S (2015). Panduan penatalaksanaan kanker payudara. PERABOI, Jakarta.

Ridha M (2017). Perbandingan jumlah seroma antara modified radical mastectomy dengan dan tanpa fiksasi flap kulit di RSUP H Adam Malik Medan. Available from https://repositori.usu.ac.id. Accessed January 12, 2020.

Ridha M, Suyatno S, Pasaribu ET (2017). Comparison of total seromas between Modified Radical Mastectomy (MRM) with and without skin flap fixation at Dr H. Adam Malik Hospital, Medan Indonesia. Bali Medica Journal 6, 357362.

Sakkary MA (2012). The value of mastectomy flap fixation in reducing fluid drainage and seroma formation in breast cancer patients. World Journal of Surgical Oncology 10, 1-6.

Sampathraju S, Rodrigues G (2010). Seroma formation after mastectomy: Pathogenesis and prevention. Indian J Surg Oncol 4, 328-333.

Skandalakis LJ, Skandalakis JE (2014). Surgical anatomy and technique: 4th ed. Springer, Atlanta. Sobri FB, Azhar Y, Wibisana IGNG, et al (2017). Manajemen terkini kanker payudara. Media Aesculapius, Jakarta.

Suyatno S, Pasaribu ET (2014). Bedah onkologi diagnosis dan terapi. Sagung Seto, Jakarta.

van Bastelaar J, Beckers A, Snoeijs M, et al (2016). Flap fixation reduces seroma in patients undergoing mastectomy: A significant implication for clinical practice. World Journal of Surgical Oncology 14, 1-5.

Yildiz BD, Sulu B (2013). Effects of dextran-40 on flap viability after modified. Can J Plast Surg 21, 83-86.

Yilmaz KB, Dogan L, Nalbant H, et al (2011). Comparing scapel, electrocautery and ultrasonic dissector effects: the impact on wound complication and pro-inflammatory cytokine levels in wound fluid from mastectomy patients. Journal of Breast Cancer 8, 58-63.

Zielinski J, Jaworski R, Irga N, et al (2013). Analysis of selected factors influencing seroma formation in breast cancer patients undergoing mastectomy. Arch Med Sci 9, 86-92.

Zollinger RM, Ellison E (2011). Zollinger's atlas of surgical operations: $9^{\text {th }}$ ed. Mc Graw Hill Medical, New York. 